\title{
THE PROPERTIES OF REGENERATIVE POLYMER MASS
}

\author{
Anna Rudawska' ${ }^{1}$ Albert Wierzchowski ${ }^{1}$, Miroslav Müller ${ }^{2}$, Jana Petrư ${ }^{3}$, Nataša Náprstková ${ }^{4}$
}

1 Mechanical Engineering Faculty, Lublin University of Technology, Nadbystrzycka 36 Str., 20-618 Lublin, Poland, e-mail: a.rudawska@pollub.pl, alberto17@interia.pl

2 Faculty of Engineering, Czech University of Life Science Prague, 165 21, Prague, Czech Republic, e-mail: muller@tf.czu.cz

${ }^{3}$ Faculty of Mechanical Engineering VSB-Technical University of Ostrava, 17. Listopadu 2172/15 1, 70800 , Ostrava, Czech Republic, e-mail: jana.petru@vsb.cz

${ }^{4}$ Faculty of Production Technology and Management, J. E. Purkyně University in Ústí nad Labem, Pasteurova 3334/7, 40096 Ústí nad Labem, Czech Republic, e-mail: naprstkova@fvtm.ujep.cz

Received: 2017.05.15

Accepted: 2017.08.01 Published: 2017.09.03

\begin{abstract}
The paper investigates the compression strength of samples of regenerative polymer mass RM 101 Resimetal Metal Repair Pasta manufactured by Rendor. The effect of weather conditions on selected mechanical properties of the tested mass is examined. The samples are subjected to seasoning at room temperature, in an environmental chamber, and in a thermal shock chamber. The samples for strength testing are made according to the adopted method. It has been observed that the samples seasoned at room temperature have the lowest strength, while the highest strength is exhibited by the samples subjected to seasoning in an environmental chamber at a temperature of $70^{\circ} \mathrm{C}$ and humidity of $95 \%$. In addition, the paper compares the strength properties of regenerative polymer masses manufactured by Chester Molecular, Belzona, and Unirep, as well as of the widely used epoxy compound Epidian 57 mixed with the Z-1 curing agent with those of the Rendor mass. The properties of the above masses are obtained from the available literature.
\end{abstract}

Keywords: regeneration, regenerative polymer mass, mechanical properties.

\section{INTRODUCTION}

A relatively advanced and widely used method for regeneration of machine parts is to apply polymer or resimetal composites [2, 5, 9]. The increased popularity of this method stems from the fact that regenerative materials exhibit relatively high mechanical properties [4, 14, 22]. Compared to other methods [24, 27], the method is relatively easy to use and, in many cases, does not require specialist tools, which leads to a significant reduction of production costs. The key parameters describing the regeneration process using regenerative polymer masses include coat's adherence to the substrate, hardness and wear resistance as well as the effect of the applied coat on the structure of native material $[1,4,6,24,26]$.
The use of polymer as regenerative masses offers numerous advantages and becomes more and more competitive $[4,10,14]$. Their advantages primarily include the possibility of quick restoration of machine part efficiency without the necessity of using special tools. Other advantages of adhesive polymers include easy coat formation, high chemical resistance, very good adherence to the surface of a regenerated part, constant mass volume during bonding, non-toxicity (with few exceptions), and non-flammability $[5,12]$. However, the use of such masses for the regeneration of machinery parts is very often constrained due to their lower mechanical properties than is the case with other regeneration methods [12].

Regenerative adhesive masses are most often cured by chemical reactions. These masses are 
often manufactured as two-component materials consisting of an adhesive substance (base) and a curing agent $[3,13,17]$. After mixing, the two components have a form of dense mass; the mixture can also be liquid, albeit rarely. They must be dosed in the exact weight or volumetric ratio recommended by the manufacturer. Otherwise, if the dosed ratio is inadequate, this can have a negative effect on the properties of the mass $[5,12$, 17]. The curing time mainly depends on the composition of a regenerative mass and, often, on the temperature in which the regenerated material is subjected to seasoning. Some adhesive materials require elevated temperatures to cure $[3,4,5$, $12]$. The base is primarily made of various epoxy resin compounds $[3,7,13]$. To improve their mechanical properties, various fillers are additionally used, e.g. metallic dust [3, 28] and others [11, 23]. Given that they have a non-uniform structure and contain two or more constituents with varying properties, adhesive plastics of this type are referred to as adhesive composites [5]. Reinforcing particles have a diameter greater than $1 \mu \mathrm{m}$, whereas their volumetric content ranges from several to several dozen percent. The addition of metal particles to the adhesive results in a significant increase in its abrasive properties, compressive strength and Young's modulus. The essence of the curing process consists in limiting the matrix formability $[3,5,12]$.

A crucial stage of the process for regenerating machine parts by the application of adhesive plastics is substrate preparation, as it affects the ultimate strength of joints [20]. The preparation consists in removing impurities and surface layer (moisture, fat, oxides) from the surface. This can be done by both mechanical and chemical methods. Another important aspect of this operation is to ensure surface development, i.e. surface roughness. This is done by mechanical processes such as abrasive blasting or grinding using different tools and methods [18, 19, 21, 25, 29].

Nowadays there is a wide spectrum of adhesive composites for various applications. They can be divided into the following 7 groups [5]:

- super metals - mainly used for reconstructing losses in metal parts; they exhibit the best functional qualities,

- liquid metals - this regenerative material in liquid form ensures both good filling of all cracks and good surface wetting,

- rapid-materials of this type are characterized by short curing times,
- slide - used for repair of sliding surfaces due to their low friction factor,

- ceramic - used for preventing erosive and cavitation wear,

- elastomers - used for regenerating rubber materials,

- coating materials - used for preventing corrosion and abrasive wear.

The aim of this study is to determine the compressive strength of samples made of the regenerative mass RM 101 Resimetal Metal Repair Pasta manufactured by Rendor. To investigate the effect of weather conditions on the properties of the mass, the samples are subjected to seasoning at room temperature, in an environmental chamber, and in a thermal shock chamber.

\section{EXPERIMENTAL METHODS}

\section{Properties of the tested regenerative polymer mass}

The tested regenerative polymer mass, RM 101 Resimetal Metal Repair Pasta, is a two-component regenerative material consisting of a base and a curing agent. After mixing the two components, the mass takes the form of dense grey paste. The curing process is caused by a chemical reaction. This mass has thixotropic properties, which means that its viscosity decreases due to intensive mixing [8].

According to the information provided by the manufacturer, prior to the application of the paste, the substrate should be prepared by abrasive blasting. The surface should have a purity of about Sa 2.5 (PN ISO 85001-1 [16]) and a roughness between $50 \mu \mathrm{m}$ and $75 \mu \mathrm{m}$. Regarding mechanically loaded elements, the thickness of the applied coat should not be smaller than $1.5 \mathrm{~mm}$ per side. The mixing ratio of base to curing agent is $3: 1$ by volume or $5: 1$ by weight. It is not recommended to mix large quantities of material at one go because the bonding process proceeds faster in a larger volume of material.

The application data of the mass at a temperature of $20^{\circ} \mathrm{C}$ are as follows:

- pot life after mixing - 25 minutes,

- time of preliminary chemical curing reaction -60 minutes,

- minimum time before machining or applying another coat -2 hours,

- full mechanical cure - 3 days,

- thickness of the applied layer - depending on the size of decrement. 
The RM 101 paste can be treated by practically any machining method including turning, milling, drilling, threading and grinding. In addition to this, the material is totally non-flammable and can be stored for 5 years after manufacture at a temperature ranging between $5^{\circ} \mathrm{C}$ and $30^{\circ} \mathrm{C}$.

\section{Preparation of regenerative mass samples}

To prepare samples of the two-component regenerative mass RM 101 Resimetal Metal Repair Pasta, the regenerative material was put in moulds until completely cured. The moulds were solids with a cylindrical hole described by the dimensions $18 \times$ x $\$ 16 \mathrm{~mm}$ (Figure 1).

Prior to putting the material in the moulds, the mass was prepared by thorough mixing of 5 weight units of the base with 1 weight unit of the curing agent using the TP-2/1 electronic scales (manufactured by FAWAG S.A. Lubelskie Fabryki Wag). Awarded the ISO9001 certificate, the scale has a measuring accuracy of $0.1 \mathrm{~g}$.
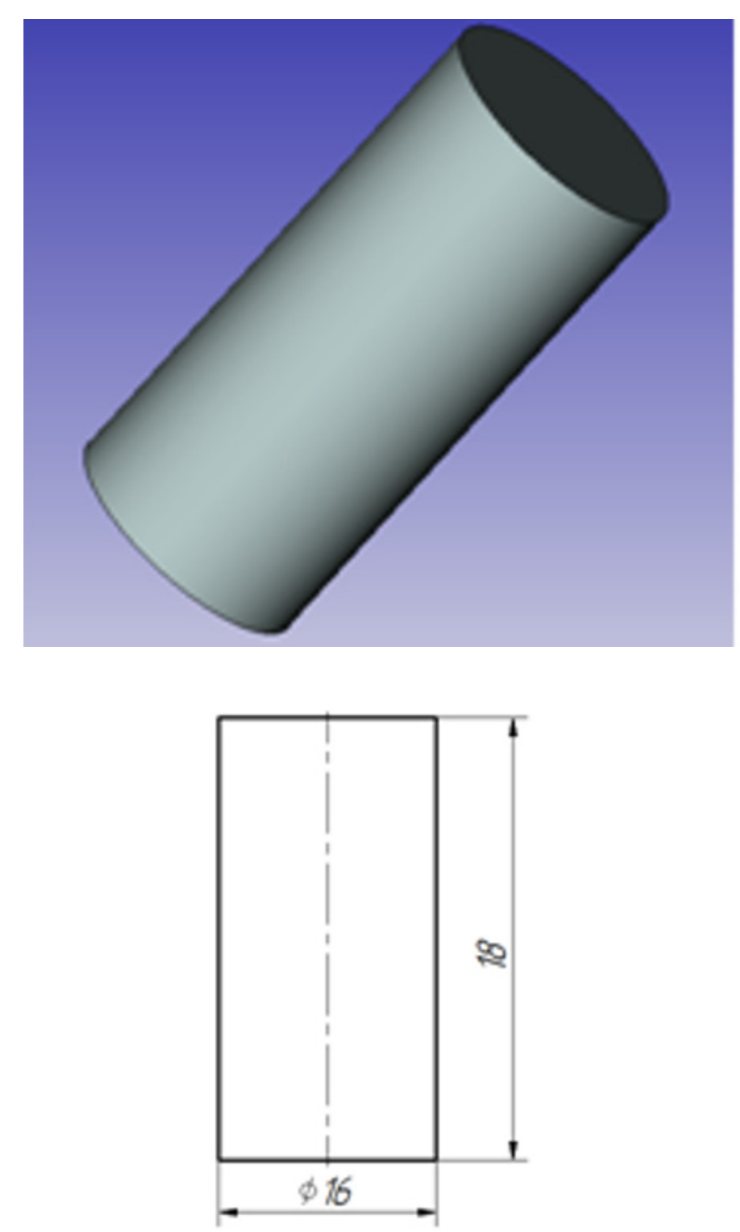

Fig. 1. Schema of regenerative polymer mass samples: a) view, b) dimensions

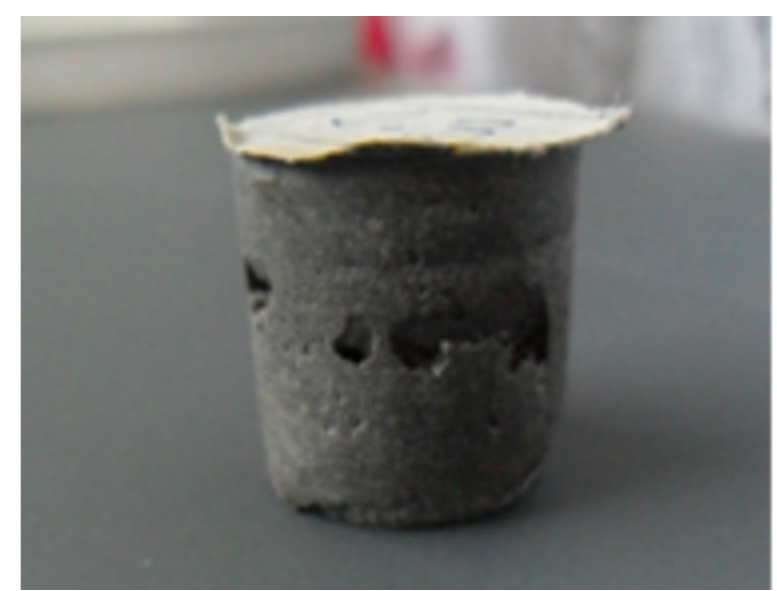

Fig. 2. Defective sample of regenerative polymer mass

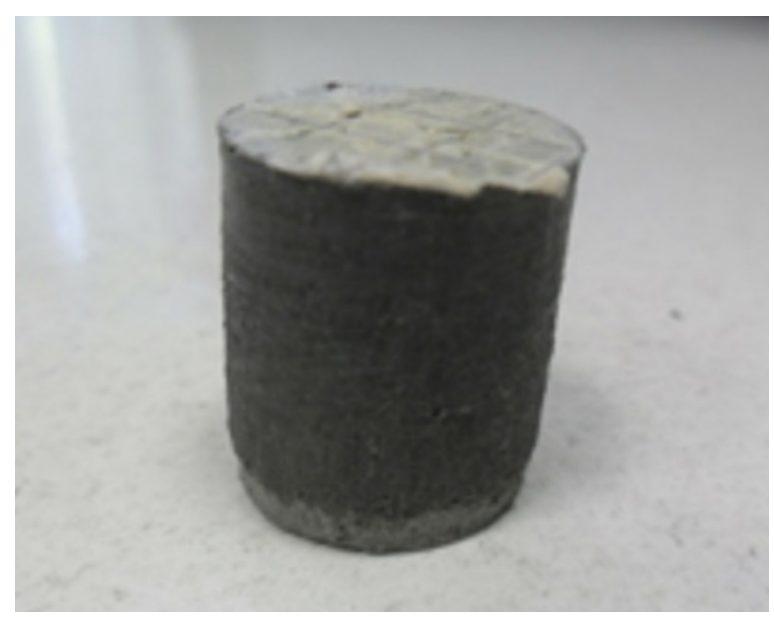

Fig. 3. Correct samples of regenerative polymer mass

The preparation of moulds involved the following operations: first, the cylindrical surface was sanded down with P500 abrasive paper; then it was wiped with a clean towel to remove dust; and finally, TECHFORM Sil was spread over the inside walls of the moulds to enable removal of the cured mass from the mould. The application of the regenerative mass consisted in feeding the mass into the mould holes and gradually pressing it down to ensure complete filling. Since the samples were made in experimental tests, it was possible to examine the way in which the regenerative mass fills a given mould. Figures 2 and 3 show the samples after extrusion from the mould where the material filled the mould incompletely (short shot) and from the mould with adequate filling, respectively.

The final stage of the preparation of regenerative mass samples for the compression test involved the removal of excess mass to make the 


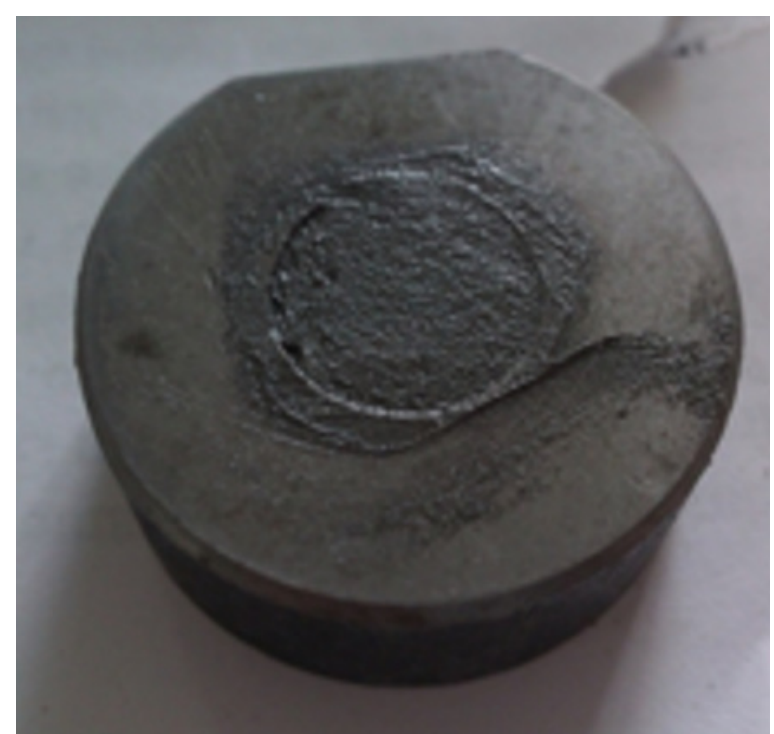

Fig. 4. Final stage of samples preparation before curing

surfaces of the samples parallel to one another. An example of the samples prior to curing (and seasoning) is shown in Figure 4.

Next, the regenerative polymer mass in moulds were subjected to curing and seasoning in compliance with the conditions described in Table 1 . Eight samples were made per each of five test runs.

The conditions define the mean temperature and humidity from the moment of production of the sample until its failure on the testing machine (samples seasoned at room temperature) or until putting it in either the environmental or the thermal shock chamber.

\section{Seasoning}

The samples and the mould were subjected to seasoning first at room temperature, then in the environmental chamber (Figure 5), and finally in the thermal shock chamber (Figure 6). The conditions of seasoning are given in Table 2 .

The experiment in the environmental chamber was performed twice. The first run of sam-
Table 1. Sample preparation conditions and their denotations

\begin{tabular}{|c|c|c|c|}
\hline $\begin{array}{c}\text { Seasoning } \\
\text { conditions }\end{array}$ & Denotation & $\begin{array}{c}\text { Temperature } \\
{\left[{ }^{\circ} \mathrm{C}\right]}\end{array}$ & $\begin{array}{c}\text { Humidity } \\
{[\%]}\end{array}$ \\
\hline $\begin{array}{c}\text { Room } \\
\text { temperature }\end{array}$ & $\mathrm{TP}$ & 25 & 40 \\
\hline $\begin{array}{c}\text { Environmental } \\
\text { chamber 1 }\end{array}$ & $\mathrm{K} 1$ & 24 & 33 \\
\hline $\begin{array}{c}\text { Environmental } \\
\text { chamber 2 }\end{array}$ & $\mathrm{K} 2$ & 24 & 38 \\
\hline $\begin{array}{c}\text { Thermal shock } \\
\text { chamber }\end{array}$ & $\mathrm{KSZT}$ & 28 & 36 \\
\hline
\end{tabular}

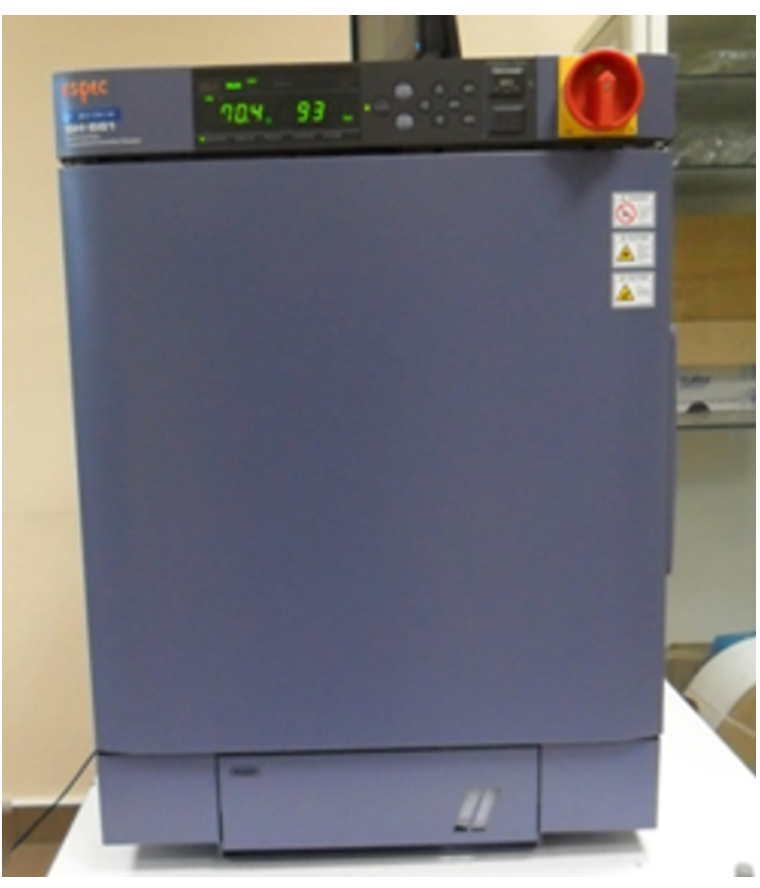

Fig. 5. Environmental chamber

ples (K1) was put in the chamber for 7 days at a constant temperature of $40^{\circ} \mathrm{C}$ and a relative humidity of $60 \%$. The second run of samples (K2) was put in the chamber for 2 weeks at a temperature of $70^{\circ} \mathrm{C}$ and a humidity of $95 \%$. The tests were performed using a environmental chamber from Espec, Espec SH-661 (Figure 5).

Table 2. Curing and seasoning conditions

\begin{tabular}{|c|c|c|c|c|c|}
\hline Denotation & Temperature $\left[{ }^{\circ} \mathrm{C}\right.$ ] & Humidity [\%] & $\begin{array}{c}\text { Time from sample } \\
\text { preparation to putting it } \\
\text { in chamber }\end{array}$ & $\begin{array}{c}\text { Seasoning } \\
\text { period }\end{array}$ & $\begin{array}{c}\text { Time from sample } \\
\text { preparation to its } \\
\text { failure }\end{array}$ \\
\hline TP & 25 & 40 & - & 3 months & 3 months \\
\hline K1 & 40 & 60 & 24 hours & 7 days & 28 days \\
\hline K2 & 70 & 95 & 5 days & 14 days & 16 days \\
\hline KSZT & $+60 /-40$ & - & 0,5 hours & 14 days & 21 days \\
\hline
\end{tabular}




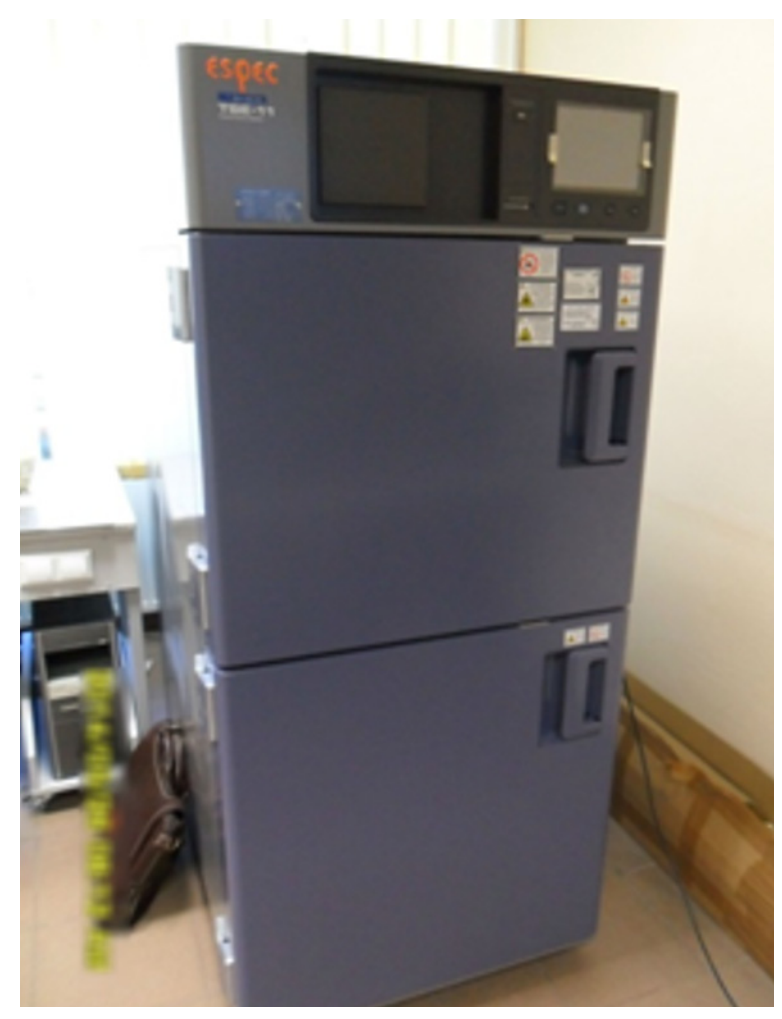

Fig. 6. Thermal shock chamber

The chamber can operate in a temperature range between $-60^{\circ} \mathrm{C}$ and $+150^{\circ} \mathrm{C}$ and at a humidity ranging from $30 \%$ to $95 \%$. It is provided with a computer terminal which enables observing changes in the chamber during the process.

The regenerative mass samples put in the thermal shock chamber (KSZT) were tested with respect to resistance to high temperature variations. The process consisted in running 300 cycles wherein the temperature was varied from $+60^{\circ} \mathrm{C}$ to $-40^{\circ} \mathrm{C}$. A single cycle lasted over 30 minutes; it included heating the samples at a temperature of $+60^{\circ} \mathrm{C}$ for 15 minutes; after that, the heated samples were moved to a cold chamber and, following temperature stabilization, kept there for 15 minutes at a temperature of $-40^{\circ} \mathrm{C}$. This experiment was performed using the Espec TSE-11 thermal shock chamber (Figure 6).

\section{Preparation of samples for strength testing}

Following the curing and seasoning, the regenerative polymer mass samples were removed from the mould by a hydraulic press provided with adequate instruments. At this stage of the experiment it was observed that the seasoning of the regenerative mass in the thermal shock chamber at varying temperatures leads to a significant deterioration in strength of the joint between the mould and the regenerative mass resulting from different thermal expansion of these materials (samples and mould). Here, the compressive force does not exceed $100 \mathrm{~kg}$, whereas with other seasoning methods - this force ranges from 900 $\mathrm{kg}$ to $1500 \mathrm{~kg}$. It can be inferred that the joint between the regenerated element and the regenerative mass subjected to seasoning in the thermal shock chamber will undergo a similar deterioration. The use of the mass under similar weather conditions is not effective, as the key parameter in the regeneration of machine parts using adhesive compounds is adhesive joint strength.

The samples were subjected to compression test on the Zwick/Roell Z150 testing machine according to the recommendations put forward in the DIN EN 196-1 standard [15] for the compression testing of concrete. Following the setting of the preliminary force to $5 \mathrm{~N}$, the samples were subjected to compression at a constant speed set to $10 \mathrm{~mm} / \mathrm{min}$. Static compression test is one of the fundamental tests for determination of mechanical properties of material.

\section{RESULTS}

\section{Strength results}

The aim of the experiments was to investigate the failure force applied to 30 samples made of RM 101 Resimetal Metal Repair Pasta. All tests were run in the same way; the sample was mounted between two flat surfaces and subjected to compressive load until the occurrence of failure strains. The results helped assess the mechanical properties of the regeneration mass as well as the effect of seasoning method and exposure to varying temperature and humidity on the compressive strength of the samples.

Experimental results and the arithmetic means of failure force, compressive strength, standard deviation and absolute strain of the tested sample runs are presented in Table 3. The example of force versus elongation of $\mathrm{K} 1$ seasoning variant is shown in Figure 7.

The results of elongation versus force (Figure 7) for the samples exposing in the climatic chamber at some conditions (Table 2) reveal that from a certain moment force increases in proportion to the deformation. From a certain moment force increases in proportion to the deformation. This means that the material is linear-elastic. After reaching the some value the force starts to 
Table 3. Mechanical properties

\begin{tabular}{|c|c|c|c|c|}
\hline Quantity & $\begin{array}{l}\text { Room temperature } \\
\text { (TP) }\end{array}$ & $\begin{array}{c}\text { Environmental } \\
\text { chamber } 40^{\circ} \mathrm{C} 60 \% \\
\text { (K1) }\end{array}$ & $\begin{array}{c}\text { Environmental } \\
\text { chamber } 70^{\circ} \mathrm{C} 95 \% \\
\text { (K2) }\end{array}$ & $\begin{array}{c}\text { Thermal shock } \\
\text { chamber } \\
\text { (KSZT) }\end{array}$ \\
\hline Mean failure force $[\mathrm{N}]$ & 15636 & 19919 & 22581 & 19167 \\
\hline Compressive strength [MPa] & 77.77 & 99.07 & 112.31 & 95.33 \\
\hline Absolute compressive strain [mm] & 1.44 & 1.50 & 1.85 & 1.62 \\
\hline Young's modulus [MPa] & 1053 & 1182 & 1131 & 1140 \\
\hline
\end{tabular}

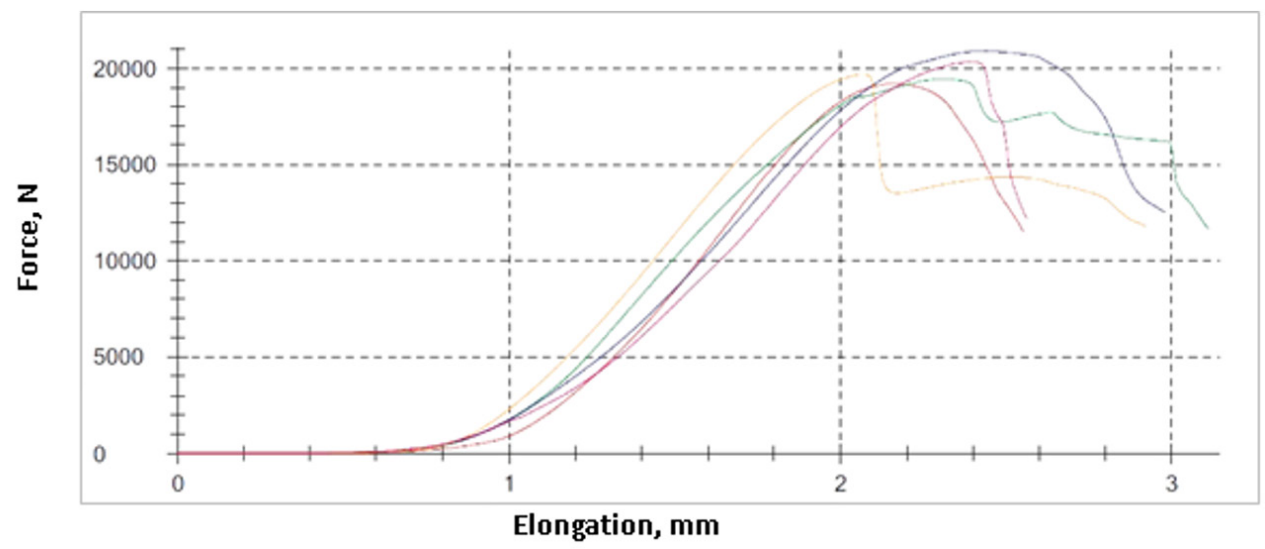

Fig. 7. Force versus elongation of K1 seasoning variant

decrease in relation to the deformation. Subsequently strength limit is crossed and thus the destruction of the sample due to the internal crack.

Mean compressive strength and standard deviation of the regenerative mass subjected to seasoning under different conditions is presented in Figure 8.

The above results (Figure 7) reveal that the lowest compressive strength is exhibited by the samples seasoned at room temperature $(77.77 \mathrm{MPa}$ ) with the maximum mean compressive force exceeding $15000 \mathrm{~N}$ (Table 3). A higher value of compressive strength is obtained for the regenerative mass samples exposed to varying temperatures in the thermal shock chamber (KSZT). It was predicted that this particular method would lead to the largest reduction in com-

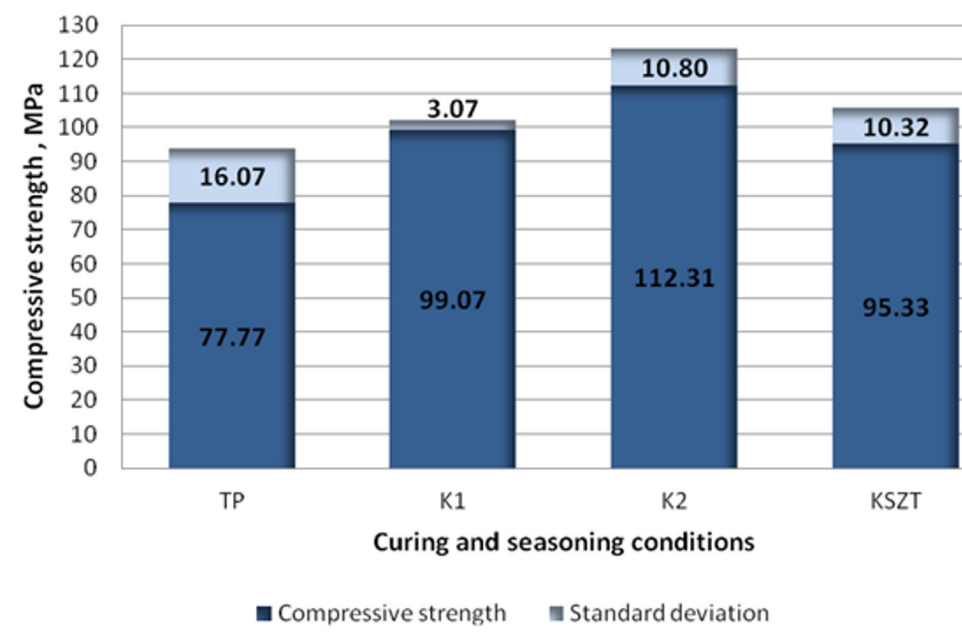

Fig. 8. Mean compressive strength and standard deviation of the regenerative mass subjected to seasoning under different conditions: TP - room temperature, K1 - environmental chamber, K2 - environmental chamber, KSZT - thermal shock chamber 


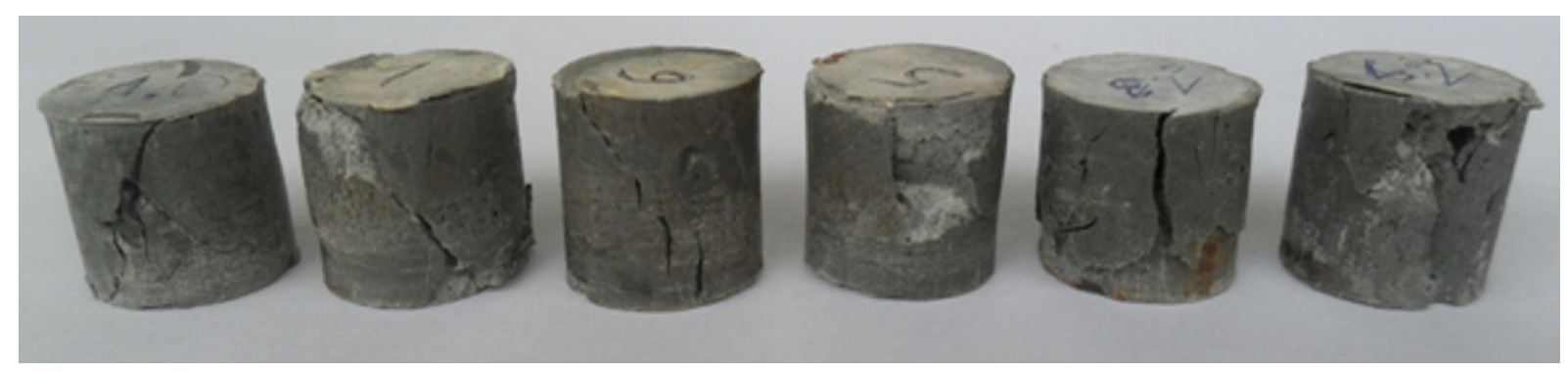

Fig. 9. Examples of samples after strength testing

pressive strength. According to the data given in Table 3, the value of mean compressive strength increased by about $23 \%$ to $95.33 \mathrm{MPa}$ compared to that of the TP run. A slightly higher strength $(99.09 \mathrm{MPa})$ is observed for the samples subjected to seasoning in the environmental chamber at a temperature $40^{\circ} \mathrm{C}$ and a humidity of $60 \%$ (K1). The highest compressive strength is exhibited by the samples subjected to seasoning in the environmental chamber at a temperature of $70^{\circ} \mathrm{C}$ and a humidity of $95 \%$ (K2). Here, the mean compressive strength is $112.31 \mathrm{MPa}$, so, compared to the TP run, it increased by $44 \%$ (34.5 MPa).

Absolute compressive strain, or the maximum length by which the samples are reduced during a compression test, does not differ to a significant degree regarding the applied seasoning methods, ranging from $1.44 \mathrm{~mm}$ (TP) to 1.85 $\mathrm{mm}$ (K2) (Table 3). This means that the sample height decreased by about $9 \%$ of the initial value. Such a high value of strain means that the tested material exhibits high plastic or elastic properties. Nonetheless, it is necessary to take account of potential errors resulting from the irregularity

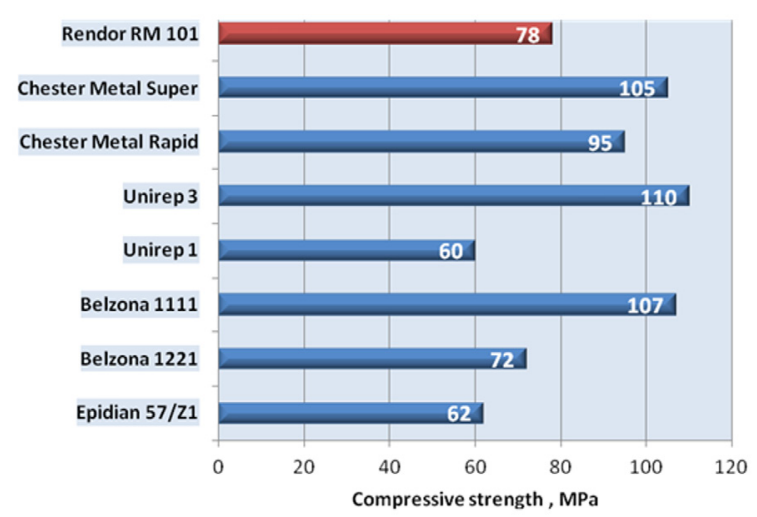

Fig. 10. Compressive strength of regenerative adhesive masses from different manufacturers (prepared based on [5]) and roughness of sample surface. Young's modulus of all tested test runs is similar and ranges between $1036 \mathrm{MPa}$ and $1182 \mathrm{MPa}$. This value indicates a high elasticity of material. This means that the material undergoes high strains at relatively low load. Figure 9 shows the examples of samples after strength testing.

In the experiments it is observed that some of the samples disintegrate with chips of material popping off to a large distance.

\section{Comparison of selected mechanical properties}

Figures 10 and 11 give a comparison of the strength properties of regenerative adhesive masses manufactured by Chester Molecular, Belzona, Unirep, the tested mass from Rendor, and the widely used Epidian 57 epoxy compound mixed with the Z-1 curing agent.

All samples were subjected to seasoning at room temperature. Three of them (Chester Metal Super, Unirep 3 and Belzona 1111) are adhesive composites belonging to the group of so called

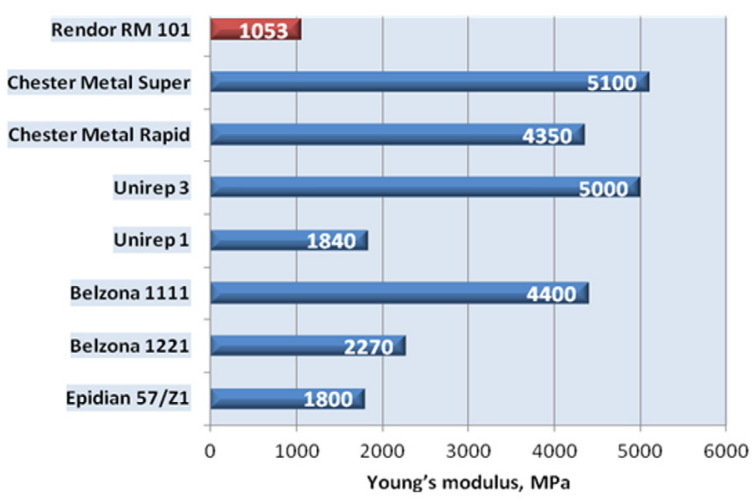

Fig. 11. Young's modulus of regenerative adhesive masses from different manufacturers (prepared based on [5]) 
"super metals." They exhibit much higher compression strength (105-110 MPa) and have higher Young's modulus (4400-5100 MPa).

Compared to super metals, the strength of Rendor RM 101 is lower by about 28\%. Young's modulus of this mass is merely $1119 \mathrm{MPa}$, but, as mentioned earlier, this value may be an error. The strength of other adhesive masses ranges from 60 $\mathrm{MPa}$ to $95 \mathrm{MPa}$ while their Young's modulus is between $1800 \mathrm{MPa}$ and $4350 \mathrm{MPa}$.

\section{CONCLUSIONS}

The study investigated the regenerative adhesive mass, RM 101 Resimetal Metal Repair Pasta, subjected to curing under four different weather conditions (room temperature, environmental chamber, thermal shock chamber) and strength testing. The compression strength of the experimental regenerative mass samples depends to a large extent on the applied seasoning method. The results do not unambiguously prove that the strength increases due to variations in the seasoning period, increased temperature or humidity, or due to the synergy effect of both parameters. In order to unambiguously determine the factors which affect the strength of the regenerative mass during curing, it is necessary to design a plan of further research with variable seasoning periods and weather conditions. Compared to other materials, the tested mass has relatively low compression strength. This parameter is not the essential characteristic defining material quality, so - with proper applications - the tested regenerative mass can meet the functional requirements and significantly reduce the time and costs of regeneration.

\section{REFERENCES}

1. Balaraju J.N., Sankara Narayanan T.S.N. and Seshadri S.K.: Electroless Ni-P composite coatings. Journal of Applied Electrochemical, 33, 2003, 807-816.

2. Baldan A. Adhesively-bonded joints and repairs in metallic alloys, polymers and composite materials: adhesives, adhesion theories and surface pretreatment. Journal of Material Science, 39, 2004, 1-49.

3. Czub P., Bończa-Tomaszewski Z., Penczek P. and Pielichowski J.: Chemia i technologia żywic epoksydowych. WNT, Warszawa, 2002.

4. Godzimirski J. and Smal T. Możliwości wykonywania połączeń z wykorzystaniem klejowych mas regeneracyjnych, Technologia i Automatyzacja Montażu, 3, 2004, 18-23.
5. Godzimirski J. Tworzywa adhezyjne: zastosowanie w naprawach sprzętu technicznego. Wydawnictwo Naukowo-Techniczne, Warszawa, 2010.

6. Godzimirski J.: Materiały i wyroby metalowe: moduł 6 według przepisów PART-66. WAT, Warszawa, 2008.

7. Harani H., Fellahi S. and Bakar M.: Toughening of epoxy resins using synthesized polyurethane prepolymer based on hydroxyl terminated polyesters. Journal of Applied Polymer Science, 70, 1998, 2603-2618.

8. Information on http://rendor.pl/upload/b3fc4cb83408.pdf (access on: 17.02.2017)

9. Kaye R. and Heller M. Finite element-base threedimensional stress analysis of composite bonded repairs to metallic aircraft structure. International Journal of Adhesion and Adhesives, 26, 2006, 261-273.

10. Kozlov H.V., Burya O.I. and Aloev V.Z.: Application of fractal fracture mechanics to polymer and polymeric composites. Materials Science, 40, 2004, 491-496.

11. Müller M., Valášek P. and Rudawska A.: Influence of filler content of mechanical properties of aluminum AL99,5 single-lap bonds bonded with aluminium and polymer powder filled epoxy adhesive. 6 th International Conference on Trends in Agricultural Engineering, 7 - 9 September 2016, Prague, Czech Republic, 412-418.

12. Nowak B.: Regeneracja typowych elementów pojazdów samochodowych. WKŁ, Warszawa, 1985.

13. Ong S., Ismail J., Abu Bakar M., Rahman I.A., Sipaut C.S. and Chee C.K.: Polyurethane-modified epoxy resin: Solventless preparation and properties. Journal of Applied Polymer Science, 111, 2009, 3094-3103.

14. Pawelec Z., Bakar M. and Kostrzewa M.: Specialized polymer composites intended for the regeneration of machine components. Problemy Eksploatacji, 3, 2015, 83-92.

15. PN-EN 196-1:2016-07. Metody badania cementu. Część 1: Oznaczanie wytrzymałości.

16. PN-EN ISO 8501-1:2008. Przygotowanie podłoży stalowych przed nakładaniem farb i podobnych produktów. Wzrokowa ocena czystości powierzchni. Część 1: Stopnie skorodowania i stopnie przygotowania niepokrytych podłoży stalowych oraz podłoży stalowych po całkowitym usunięciu wcześniej nałożonych powłok.

17. Rudawska A. and M. Czarnota M.: Selected aspects of epoxy adhesive compositions curing process. Journal of Adhesion Science and Technology, 27, 2013, 1933-1959.

18. Rudawska A. Selected aspects of the effect of mechanical treatment on surface roughness and adhesive joint strength of steel sheets. International Journal of Adhesion and Adhesives, 50, 2014, 235-243. 
19. Rudawska A., Danczak I., Müller M. and Valasek P.: The effect of sandblasting on surface properties for adhesion. International Journal of Adhesion and Adhesives, 2016, 70, 176-190.

20. Rudawska A., Nalepa J. and Müller M.: The effect of degreasing on adhesive joint strength. Advances in Science and Technology Research Journal, 11 (1), 2017, 75-81.

21. Rudawska A., Reszka M., Warda T., Miturska I., Szabelski J., Stancekova D. and Skoczylas A.: Milling as a method of surface pre-treatment of steel for adhesive bonding. Journal of Adhesion Science and Technology, 2016, 30, 2619-2636.

22. Smal T. Badanie właściwości wytrzymałościowych kompozytu klejowego i ich związek z okresem przechowywania. Technologia i Automatyzacja Montażu, 3-4, 2004, 101-103.

23. Suberlyak O., Krasinskyi V., Moravskyi V., Gerlach H. and Jachowicz T.: Influence of aluminosilicate filler on the physicomechanical properties of polypropylene-polycaproamide composites. Materials Science, 50, 2015, 296-302.
24. Ścieszka S.F. and Żołnierz M.: Eksploatacja maszyn, część 1. Wydawnictwo Politechniki Śląskiej, Gliwice, 2012.

25. Świć A., Draczew A. and Gola A.: Method of achieving accuracy of thermo-mechanical treatment of low-rigidity shafts. Advances in Science and Technology. Research Journal, 10, (29), 2016, 62-70.

26. Trzaska M.: Warstwy kompozytowe Ni-P/Si3N4 wytwarzane metodą chemiczną na aluminium i jego stopach. Inżynieria Materiałowa, 29, 2008, 657-660.

27. Tyra A., Świerczyński S. and Poreda A.: Regeneracja części maszyn i urządzeń. Wydawnictwo MCNEMT, Radom, 1989.

28. Wang P.-H., Wu Y.-Z. and Zhu Q.-R.: Polymer metal composite particles: polymer core and metal shell. Journal of Material Science, 21, 2002, 1825-1828.

29. Zaleski K. and Bławucki S.: Evaluation of the Effectiveness of the Shot Peening Process for Thin-Walled Parts Based on the Diameter of Impression Produced by the Impact of Shot Media. Advances in Science and Technology Research Journal, 9, (26), 2015, 77-82. 